\title{
Review \\ Schiff Bases: Interesting Scaffolds with Promising Antitumoral Properties
}

\author{
Domenico Iacopetta ${ }^{1}$, Jessica Ceramella ${ }^{1}$, Alessia Catalano ${ }^{2, *}$ (D) , Carmela Saturnino ${ }^{3, *(D)}$, \\ Maria Grazia Bonomo ${ }^{3}$, Carlo Franchini ${ }^{2}$ and Maria Stefania Sinicropi ${ }^{1}$ (D) \\ 1 Department of Pharmacy, Health and Nutritional Sciences, University of Calabria, 87036 Arcavacata di Rende, \\ Italy; domenico.iacopetta@unical.it (D.I.); jessicaceramella@gmail.com (J.C.); s.sinicropi@unical.it (M.S.S.) \\ 2 Department of Pharmacy-Drug Sciences, University of Bari “Aldo Moro", 70126 Bari, Italy; \\ carlo.franchini@uniba.it \\ 3 Department of Science, University of Basilicata, 85100 Potenza, Italy; mariagrazia.bonomo@unibas.it \\ * Correspondence: alessia.catalano@uniba.it (A.C.); carmela.saturnino@unibas.it (C.S.); \\ Tel.: +39-0805442731 (A.C.); +39-097126442 (C.S.)
}

check for updates

Citation: Iacopetta, D.; Ceramella, J.; Catalano, A.; Saturnino, C.; Bonomo, M.G.; Franchini, C.; Sinicropi, M.S. Schiff Bases: Interesting Scaffolds with Promising Antitumoral

Properties. Appl. Sci. 2021, 11, 1877. https://doi.org/10.3390/app11041877

Academic Editor: Fethi Bedioui

Received: 2 February 2021

Accepted: 17 February 2021

Published: 20 February 2021

Publisher's Note: MDPI stays neutral with regard to jurisdictional claims in published maps and institutional affiliations.

Copyright: (c) 2021 by the authors. Licensee MDPI, Basel, Switzerland. This article is an open access article distributed under the terms and conditions of the Creative Commons Attribution (CC BY) license (https:// creativecommons.org/licenses/by/ $4.0 /)$.

\begin{abstract}
Schiff bases, named after Hugo Schiff, are highly reactive organic compounds broadly used as pigments and dyes, catalysts, intermediates in organic synthesis, and polymer stabilizers. Lots of Schiff bases are described in the literature for various biological activities, including antimalarial, antibacterial, antifungal, anti-inflammatory, and antiviral. Schiff bases are also known for their ability to form complexes with several metals. Very often, complexes of Schiff bases with metals and Schiff bases alone have demonstrated interesting antitumor activity. Given the innumerable vastness of data regarding antitumor activity of all these compounds, we focused our attention on monoand bis-Schiff bases alone as antitumor agents. We will highlight the most significant examples of compounds belonging to this class reported in the literature.
\end{abstract}

Keywords: Schiff bases; antitumor agents; apoptosis; antiproliferative activity; imines

\section{Introduction}

Since their discovery by the German chemist Hugo Schiff [1], Schiff bases (imines), scaffolds with high chemical reactivity, and their metal complexes have been very well known for catalysis in various synthetic processes and for their biological properties. In therapy, Schiff bases and their metal complexes have been reported to manifest a wide range of biological activities [2,3] such as antimicrobial [4], ureases inhibitory [5], anti-inflammatory [6,7], anti-ulcerogenic [8], antioxidant [9-11], pesticidal, cytotoxic, and anticancer [12] including DNA damage [13-15]. Schiff bases have been also successfully used in scientific studies [16] as highly efficient and selective sensing materials for optical, electrochemical [17,18], and membrane sensors [19]. Zinc-Schiff bases have been proposed as carrier vehicles for the delivery of zinc to prostate cells. Indeed, the use of the membrane-penetrating peptide Novicidin connected to zinc-Schiff base has been studied as a therapeutic approach for prostate cancer [20]. Schiff base ligands, as some other organic small molecules [21], have received great attention from researchers thanks to their easy preparation and ability to form complexes with almost all metals, due to the electron-donating nitrogen in their base structure [22-24]. Several metal complexes, in which the metal is coordinated to various ligands, are able not only to stabilize the metal but also to modify its chemical and pharmaceutical properties and are receiving attention in medicinal chemistry [25-30]. The general structure of a Schiff base is shown in Figure 1, $\mathrm{R}^{1}, \mathrm{R}^{2}$ and $\mathrm{R}^{3}$ being an alkyl or aryl moiety. 
<smiles>[R]N=C([R])[R]</smiles>

Figure 1. General structure of a Schiff base.

Schiff bases are particularly interesting in the field of antitumor agents [31-34] as many other small organic molecules (for instance, diarylureas [35], indoles [36,37], carbazoles [38], phthalimides [39], and so on [40,41]). The most salient and recent data on Schiff bases will be, herein, reviewed.

For instance, in a recent study, the introduction of Schiff bases in the N-phenylcarbazole/ triphenylamine modified half-sandwiched iridium(III) compounds determined an enhancement of antitumor activity of about 13 times that of the clinical cisplatin [42]. This review focused on studies of the last decades on mono- and bis-Schiff bases as antiproliferative agents, paying attention particularly on Schiff bases showing high activity (concentration which kills or inhibits cell viability by $50 \%$ ( $\left.\mathrm{IC}_{50}\right)$ in the range of micromolar to nanomolar).

\section{Schiff Bases as Antiproliferative Agents}

\subsection{Mono-Schiff Bases}

Vicini et al. (2003) [43] studied a series of Schiff bases and tested their antiproliferative activity against a panel of human cell lines derived from hematological and solid tumors. The most interesting compounds were 1-3 (Table 1). All of them inhibited the growth of leukemia cell lines, with $\mathrm{IC}_{50}$ values ranging between 1.5 and $7 \mu \mathrm{M}$ against human $\mathrm{CD}^{+}$ lymphocytes (MT-4), human CD4 ${ }^{+}$acute T-lymphoblastic leukemia (CCRF-CEM), human splenic B-lymphoblastoid cells (WIL-2NS), and human acute B-lymphoblastic leukemia (CCRF-SB). The 2-Amino-6-mercaptopurine was used as reference drug $\left(\mathrm{IC}_{50}\right.$ between 0.1 and $0.5 \mu \mathrm{M})$. Particularly, compound 3 was also active against solid tumor-derived cell lines' skin melanoma and breast adenocarcinoma cells ( $\mathrm{IC}_{50}=6$ and $10 \mathrm{nM}$ ) against human skin melanoma SK-MEL-28 and human breast adenocarcinoma MCF-7 cell lines, respectively. The values for 2-amino-6-mercaptopurine were 5 and $4 \mu \mathrm{M}$, respectively. Zhou et al. (2007) [44] studied several imines bearing thiazole and triazole moieties and evaluated their antiproliferative activities against leukemia, stomach, and larynx cancer cell lines. The 2,4-dinitro substituted Schiff base 4 displayed high activity against HL-60, BGC-823 and Hep-2 cell lines, showing percentage inhibition of 91.97, 98.49, and 91.16\%, respectively. Abdel-Hafez et al. (2009) [45] studied several Schiff bases as derivatives of xanthotoxin and evaluated their antitumor activities against cervical carcinoma (HeLa) and breast carcinoma (MCF 7) cell lines. The Schiff base 5 was inactive against MCF-7 cell line but was the most interesting against $\mathrm{HeLa}$, showing an $\mathrm{IC}_{50}$ value of $7.2 \mu \mathrm{M}$ and a percent viability of $70 \%$ (xanthotoxin, $7.6 \mu \mathrm{M}$ and $62 \%$, respectively). Kraicheva et al. (2009) [46] studied three Schiff bases and evaluated their antiproliferative activity, using the 3-[4,5-dimethylthiazol-2-yl]-2,5-diphenyltratrazolium bromide (MTT) assay, against four human leukemic cell lines, viz., LAMA-84 (peripheral chronic myeloid leukemia cells), K-562 (non-adherent chronic myelogenous leukemia cells of the erythroleukemia type), HL-60 (acute promyelocytic leukemia cells) and its multi-drug-resistant sub-line HL-60/Dox (multi-drug resistant acute myeloblastic leukemia cell line), characterized by the overexpression of MRP-1 protein (ABC-C1). Compound $\mathbf{6}$ showed antiproliferative activity $\left(\mathrm{IC}_{50}=39.9 \mu \mathrm{M}, 29.9 \mu \mathrm{M}\right.$, and $68.6 \mu \mathrm{M}$ against LAMA-84, K-562, and HL-60/Dox, respectively), while compound 7 was less active $\left(\mathrm{IC}_{50}=251.9 \mu \mathrm{M}, 212.9 \mu \mathrm{M}\right.$, and $226.1 \mu \mathrm{M}$ against LAMA-84, K-562, and HL-60/Dox, respectively). Both the investigated compounds were identified as capable of evoking the distinctly marked lower cytotoxic effects (with the $\mathrm{IC}_{50}$ values over $400 \mu \mathrm{M}$ ) against the sensitive leukemic cell line HL-60 in a preliminary antitumor screening.

Nawaz et al. (2009) [47] studied Schiff bases with ferrocene addition and evaluated their antitumor, antioxidant, and DNA-protecting activities. Antitumor activity was eval- 
uated by Potato disc tumor induction assay using Agrobacterium tumefaciens (At-10) to induce tumors on potato discs, that is, a prescreen assay and its results were in accordance with other commonly used in vitro antitumor assays. All the tested compounds inhibited tumor production for treatment of 1000,100, and $10 \mu \mathrm{g} / \mathrm{mL}$ concentration at $p<0.05$ (vincristine, used as positive control, showed $100 \%$ tumor inhibition at all concentrations tested). The inhibition was observed in a dose-dependent manner with the highest inhibition at $1000 \mu \mathrm{g} / \mathrm{mL}$ concentration. Moreover, the highest tumor growth inhibition of $71 \%$ was observed with ferrocene containing Schiff base 8, followed by 9 with $58 \%$ inhibition at $1000 \mu \mathrm{g} / \mathrm{mL}$. IC 50 values were 20 and $563 \mu \mathrm{g} / \mathrm{mL}$ versus $0.003 \mu \mathrm{g} / \mathrm{mL}$ of vincristine. Zaheer et al. (2010) [48] studied several Schiff bases and tested their cytotoxic activity by the brine shrimp lethality assay. Medium lethal concentration $\left(\mathrm{LD}_{50}\right)$ values for compounds 10 and 11 were 292.95 and 18.22 ppm, respectively.

Cheng et al. (2010) [49] studied eight Schiff bases and evaluated their antiproliferative effects on human hepatoma HepG2 cells by sulforhodamine B assay. Compounds 12 and 13 were comparable to positive control, etoposide, showing $\mathrm{IC}_{50}$ values of 5.6 and $6.8 \mu \mathrm{M}$, respectively, versus $4.1 \mu \mathrm{M}$ of etoposide. Jesmin et al. (2010) [50] studied two Schiff bases, PHP [N-(1-phenyl-2-hydroxy-2-phenylethylidine)-2-hydroxylphenylimine, 14) and HHP [N-(2-hydroxybenzylidine)-2-hydroxylphenylimine, 15) as anticancer agents acting on Ehrlich ascites carcinoma (EAC) cells in Swiss albino mice. All compounds were more active than standard anticancer drug, bleomycin, in improving the life span, lowering tumor weight, and inhibiting the tumor cell growth of EAC cell-bearing mice. The toxicity of the tested compounds was evaluated by measuring $\mathrm{LD}_{50}$ values that were of 16 and $15.5 \mathrm{mg} / \mathrm{kg}$ for $\mathbf{1 4}$ and 15, respectively. The maximum percentage cell growth inhibition of $93 \%$ was observed with 15 with dose loading of $2 \mathrm{mg} / \mathrm{kg}$. Etaiw et al. (2011) [51] studied a Schiff base derived from 2-aminobenzothiazole and 2-thiophenecarboxaldehyde (16) for its antiproliferative activity against five human cancer cell lines (cervical carcinoma, HeLa; breast carcinoma, MCF-7; liver carcinoma, HepG2; colon carcinoma, HCT-116; and larynx carcinoma, HEP2). Compound $\mathbf{1 6}$ showed activity against HeLa cancer cells $\left(\mathrm{IC}_{50}=\mathrm{T} 0.186 \mu \mathrm{M}\right)$. Moreover, its complexes with $\mathrm{Cu}(\mathrm{II}), \mathrm{Fe}(\mathrm{III})$, and $\mathrm{Ni}(\mathrm{II})$ showed a higher activity. Hranjec et al. (2011) [52] prepared series of 14 imines and studied the suppression of proliferation of different human cancer cell lines (HeLa (cervical carcinoma), SW620 (colorectal adenocarcinoma, metastatic), MiaPaCa-2 (pancreatic carcinoma), MCF-7 (breast epithelial adenocarcinoma, metastatic)) and their cytotoxic activity on normal human fibroblasts (WI38 normal diploid human fibroblasts) using the MTT assay. Compounds 17 and 18 exerted a strong non-specific antiproliferative effect on all cell lines tested and a concentration-dependent effect on HeLa and MCF-7 cell lines at micromolar concentrations $\left(\mathrm{IC}_{50}=4.73\right.$ and $3.24 \mu \mathrm{M}$ on HeLa and 9.23 and $15.27 \mu \mathrm{M}$ on MCF-7). However, they were also highly cytotoxic on human fibroblasts. Shaker et al. (2011) [53] synthesized surfactants containing Schiff bases with hydrocarbon chains of different lengths (from C12 to C18). In vitro anticancer cytotoxic activity of these compounds was investigated using EAC as a model system of mice cell tumor at different concentrations (25,50, and 100\%) against liver carcinoma (HepG2), breast carcinoma (MCF-7), and colon carcinoma (HCT-116) cell lines. Compound 19, bearing a C14 hydrocarbon chain, caused the death of $95 \%$ of EAC cell at the highest concentration. The $\mathrm{IC}_{50}$ values for compound 19 at different concentrations ranged from 1 to $10 \mathrm{mg} / \mathrm{mL}$. It showed high activity in in vitro system on the tumor cell lines investigated and the highest cytotoxic effect on HepG2, HCT-116, and MCF-7, respectively, and SBC12 surfactant-affected tumor tissue at very low concentrations at values lower than their critical micelle concentration ( $\mathrm{cmc}$ ) values.

Kraicheva et al. (2012) [54] synthesized two anthracene-containing Schiff bases, 9anthrylidene-p-toluidine (20) and 9-anthrylidene-furfurylamine (21), and tested their anticancer activities in vitro on a panel of human epithelial cancer cell lines (cell lines from ductal carcinoma of the breast with low and high metastatic potential, MCF-7 and MDAMB-231, respectively; colostrum-derived myoepithelial cells, expressing polyoma virus large T-antigen, HBL-100 line; bladder carcinoma, 647-V; hepatocellular carcinoma, HepG2; 
colon carcinoma, HT-29; cervical carcinoma, HeLa). Compounds 20 and 21 showed high cytotoxic activity toward colon carcinoma HT-29 cell line $\left(\mathrm{IC}_{50}=0.08\right.$ and $0.20 \mathrm{mg} / \mathrm{mL}$ versus $0.58 \mathrm{mg} / \mathrm{mL}$ of doxorubicin). The authors also performed their safety testing, both in vitro (Neutral Red Uptake Assay, 3T3 NRU test) and in vivo on ICR mice for genotoxicity and antiproliferative activity. Both compounds were shown not to induce clearly expressed dose-effect clastogenic activities, in contrast to the alkylating agent Mitomycin C. Bae et al. (2012) [55] synthesized new Schiff bases and evaluated their anti-melanogenesis activity, in murine B16F10 melanoma cells, through the inhibition of tyrosinase. Compound 12 exhibited the most potent and non-competitive inhibition on mushroom tyrosinase, even better than the kojic acid used as positive reference $\left(\mathrm{IC}_{50}\right.$ value of $17.22 \mu \mathrm{M}$ versus $51.11 \mu \mathrm{M}$ of the kojic acid). This compound decreased the melanin production stimulated by the alpha-melanocyte-stimulating hormone and inhibited murine tyrosinase activity in a dose-dependent manner. Sondhi et al. (2012) [56] synthesized several mono-Schiff bases and bis-Schiff bases and studied their anticancer activities against five human cancer cell lines (lung, NCI H-522; ovary, PA1; breast T47D; colon, HCT-15; liver, HepG2) by MTT assay. The percentage growth (PG) inhibition of cancer cell lines was determined at a concentration of $1 \times 10^{-5} \mathrm{M}$. The most active mono-Schiff base against lung cancer cells ( $49 \%$ versus $59 \%$ of actinomycin-D) was compound 22 . The other active bis-Schiff bases are reported in the next paragraph. Klimczak et al. (2013) [57] studied several small molecules bearing an imine moiety and studied their activity against four esophageal cancer cell lines. Compound 23 was the most active of the series, showing $\mathrm{IC}_{50}$ values of 50.12, 158.49, and $111.2 \mu \mathrm{M}$ against KYSE 150, KYSE 30 and KYSE 270.

Hafez et al. (2013) [58] studied several Schiff bases as antiproliferative agents against various cell lines by using the MTT assay. The most interesting compounds, more active than standard drugs, were 24-26. In particular, 24 was active on ovarian carcinoma (SK OV-3) cell line ( $\mathrm{IC}_{50}=0.44 \mu \mathrm{M}$ versus $4.16 \mu \mathrm{M}$ of doxorubicin), whereas compound 25 showed good activity on leukemia (U937) $\left(\mathrm{IC}_{50}=0.09 \mathrm{nM}\right.$ versus 4.45 of doxorubicin), neuroblastoma (GOTO and NB-1) ( $\mathrm{IC}_{50}=0.45 \mathrm{nM}$ and $0.64 \mathrm{nM}$, respectively, versus $\mathrm{IC}_{50}=4.73 \mathrm{nM}$ and $\mathrm{IC}_{50}=5.15 \mathrm{nM}$, respectively, of doxorubicin), and fibrosarcoma (HT1080) cell lines ( $\mathrm{IC}_{50}=0.54 \mathrm{nM}$ versus $1.16 \mathrm{nM}$ of tamoxifen). Finally, compound $\mathbf{2 6}$ was active on cervical carcinoma $(\mathrm{KB})\left(\mathrm{IC}_{50}=0.54 \mu \mathrm{M}\right.$ versus $4.46 \mu \mathrm{M}$ of fluorouracil), CNS (SF268) $\left(\mathrm{IC}_{50}=0.30 \mathrm{nM}\right.$ versus $7.68 \mathrm{nM}$ of cytarabine), leukemia $(\mathrm{K}-562)\left(\mathrm{IC}_{50}=0.43 \mathrm{nM}\right.$ versus 6.66 of doxorubicin), liver (HepG2) ( $\mathrm{IC}_{50}=0.09 \mathrm{nM}$ versus $1.31 \mathrm{nM}$ of tamoxifen), and nonsmall cell lung ( $\mathrm{NCI} H 460)$ cancer cell lines $\left(\mathrm{IC}_{50}=6.60 \mathrm{nM}\right.$ versus $2.13 \mathrm{nM}$ of gencitabine hydrochloride). Hassan et al. (2015) [59] synthesized several imines and evaluated their cytotoxicity against four human cancer cell lines (colon HCT-116, lung A549, breast MCF-7, and liver HepG2) according to Sulforhodamine-B stain (SRB) assay. Compound 27 was the only compound to show slight activity against liver HepG2 $\left(\mathrm{IC}_{50}=6.20 \mu \mathrm{g} / \mathrm{mL}\right)$ and breast MCF-7 ( $\mathrm{IC}_{50}=7 \mu \mathrm{g} / \mathrm{mL}$ ) cells in comparison with the standard drug, doxorubicin $\left(\mathrm{IC}_{50}=4.20\right.$ and $4.70 \mu \mathrm{g} / \mathrm{mL}$, respectively $)$.

Zhao et al. (2013) [60] studied a series of Schiff bases and evaluated the in vitro antiproliferative activities against human breast cancer cell MCF-7 and mouse lymphocyte leukemia cell L1210 by the WST-8 ([2-(2-methoxy-4-nitrophenyl)-3-(4-nitrophenyl)-5-(2,4disulfophenyl)-2H-tetrazolium monosodium salt]) assay as a substitute for the most classic MTT assay. The lead compound 2-phenyl-4-carboxyl-1,3-selenazole (PCS) was taken as a comparison. Compounds $\mathbf{2 8 - 3 0}$ were the most potent compounds against MCF-7 $\left(\mathrm{IC}_{50}=4.02,7.55\right.$ and $8.51 \mu \mathrm{M}$, respectively, versus $16.56 \mu \mathrm{M}$ of PCS). Compound 31 was the most active against $\mathrm{L} 1210$ ( $\mathrm{IC}_{50}=38.73 \mu \mathrm{M}$ versus $60.11 \mu \mathrm{M}$ of PCS). Noureen et al. (2013) [61] reported a study on Schiff bases and evaluation of their antioxidant, antitumor, and anti-inflammatory potentials. The antitumor activity was assessed by the potato disc anti-tumor assay. Compounds $\mathbf{3 2}$ and $\mathbf{3 3}$ were the most active, showing $\mathrm{IC}_{50}$ values of 0.15 and $8.03 \mu \mathrm{g} / \mathrm{mL}$, respectively, versus $0.003 \mu \mathrm{g} / \mathrm{mL}$ of vincristine, used as reference drug.

Zhang et al. (2014) [62] synthesized a series of Schiff bases and evaluated the in vitro antitumor activity against three human tumor cell lines (human liver SMMC-7721, hu- 
man breast MCF-7, and human lung A549) using the WST-8 assay and 5-Fluorouracil (5-FU) as a positive control. Compound 34 was the most active against SMMC-7721 cells $\left(\mathrm{IC}_{50}=2.84 \mu \mathrm{M}\right.$ versus $\left.5-\mathrm{FU}, \mathrm{IC}_{50}=5.62 \mu \mathrm{M}\right)$, whereas compounds 35 and 36 showed significant antiproliferative activity against MCF-7 cells $\left(\mathrm{IC}_{50}=4.56\right.$ and $4.25 \mu \mathrm{M}$, respectively, versus $14.26 \mu \mathrm{M}$ of 5-FU). Finally, the most interesting compounds against A549 cells were 37 and $36\left(\mathrm{IC}_{50}=4.11\right.$ and $4.13 \mu \mathrm{M}$, respectively, versus $8.13 \mu \mathrm{M}$ of 5-FU). Gupta et al. (2015) [63] synthesized 13 Schiff bases and studied their potential as Hsp 90ATPase inhibitors by malachite green assay and antiproliferative activity against PC3 prostate cancer cell lines by MTT assay. Compound 38 showed a high effect toward PC3 cells with an $\mathrm{IC}_{50}$ of $4.83 \mu \mathrm{M}$ (versus $2.45 \mu \mathrm{M}$ of geldanamycin), followed by compounds 39 and $40\left(\mathrm{IC}_{50}=7.43 \mu \mathrm{M}\right.$ and $7.15 \mu \mathrm{M}$, respectively), which were the other promising anticancer molecules among the newly synthesized compounds. In malachite green assay for Hsp90 ATPase suppression, none of the molecules demonstrated $\mathrm{IC}_{50}$ values in nanomolar range. Only compounds 41 and 42 showed the maximum inhibitory potential, with an $\mathrm{IC}_{50}$ value of $0.02 \mu \mathrm{M}$. In conclusion, the authors identified the compound 38, showing sub micro-molar target affinity and good cellular potency, as the lead molecule for preclinical evaluation in animals and development of Hsp90 inhibitors as anticancer agents. Abd-Elzaher et al. (2016) [64] synthesized and studied a Schiff base ligand (43) and its complexes with metal ions. Compound 43 was tested for its anticancer activity against different human tumor cell lines (liver HepG2, breast MCF-7, and colorectal HCT116) and doxorubicin was used as a reference drug. It showed $\mathrm{IC}_{50}=9.22,10.00$, and $9.50 \mu \mathrm{M}$ against the tree cell lines, respectively ( $\mathrm{IC}_{50}$ values for doxorubicin were $4.20,4.40$, and $5.25 \mu \mathrm{M}$, respectively).

Sabbah et al. (2018) [65] described the design, synthesis, and biological evaluation of new phenylimino-1,2-diphenylethanol derivatives in human colon carcinoma (HCT116), breast adenocarcinoma (MCF-7), and breast carcinoma (T47D) cell lines. Among the tested compounds, the authors evidenced a selectivity toward the adopted cells lines, indicating that the highest inhibitory activity toward the MCF-7 and T47D cells was obtained under the imine 44 treatment $\left(\mathrm{IC}_{50}\right.$ values of 0.024 and $0.034 \mathrm{M}$, respectively). Moreover, they suggested that this different selectivity could depend on the difference forms of the phosphatidylinositol 3-kinases (PI3Ks) present in the adopted cell models. This hypothesis was proven by the means of in silico and in vitro studies, indicating that the phosphoinositide 3-kinase $\alpha(\mathrm{PI} 3 \mathrm{~K} \alpha)$ is one of the targets of the compound 44, which influences the fundamental PI3K/Akt signaling pathway [66] leading, ultimately, to cancer cell apoptosis. At the same time, compound $\mathbf{4 4}$ reduces the expression of the Vascular Endothelial Growth factor (VEGF) in MCF-7 cells, suggesting a role in inhibiting the angiogenesis process. However, no evidence about the effects on normal cell lines has been reported. Hassan et al. (2018) [67] described a series of Schiff bases and evaluated their antiproliferative activities against HepG2 (liver) and MCF-7 (breast) cell lines using the MTT assay. The majority of prepared Schiff bases displayed better antitumor activity than doxorubicin. Compounds $\mathbf{4 5}$ and $\mathbf{4 6}$ were the most interesting of the series. Compound 45 was the most active against HepG2 cell line compared to doxorubicin $\left(\mathrm{IC}_{50}=66.3 \mu \mathrm{M}\right.$ versus $80.9 \mu \mathrm{M})$, while compound 46 showed high activity against $\mathrm{MCF}-7\left(\mathrm{IC}_{50}=60.8 \mu \mathrm{M}\right.$ versus $65.6 \mu \mathrm{M}$ of doxorubicin). They were also demonstrated to induce apoptosis in HepG2 and MCF-7, increasing the caspase-3 levels. Hassanin et al. (2018) [68] reported a series of Schiff bases bearing a pyranoquinolinone moiety. They were evaluated for topoisomerase II $\beta$ (TOP2B) inhibitory activity $[69,70]$ and cytotoxicity against breast cancer cell line (MCF7). The compounds 47-49 displayed a significant TOP2B cytotoxicity compared to the reference doxorubicin $\left(\mathrm{IC}_{50}=0.042,0.83\right.$, and $0.6 \mu \mathrm{M}$ versus $\mathrm{IC}_{50}=1.17 \mu \mathrm{M}$ of doxorubicin).

Several Schiff bases derived from 2-aminobenzothiazole were reported by Saipriya et al. (2018) [71], who performed in vitro MTT assay on HeLa cell lines to validate the cytotoxic activity against cervical cancer cells. Compound $\mathbf{5 0}$ showed high activity with an $\mathrm{IC}_{50}$ value of $2.517 \mu \mathrm{g} / \mathrm{mL}$ (cisplatin: $\mathrm{IC}_{50}=17.2 \mu \mathrm{g} / \mathrm{mL}$ ). Uddin et al. (2019) [72] studied a series of Schiff bases and evaluated their cytotoxicity against cancer cell lines (HeLa and 
MCF-7) and a normal cell line (BHK-21) by means of the MTT assay. Compounds 51 and $\mathbf{5 3}$ showed a slight cytotoxic activity against $\mathrm{HeLa}\left(\mathrm{IC}_{50}=56.7\right.$ and $20.8 \mu \mathrm{M}$, respectively, versus $5.13 \mu \mathrm{M}$ of carboplatin) and BHK-21 cells ( $\mathrm{IC}_{50}=32.2$ and $60.2 \mu \mathrm{M}$, respectively). The mechanism of action for the active compound L5 was deepened, studying the pro-apoptotic mechanism by fluorescence microscopy, cell cycle analysis, caspase- 9 and -3 activity, reactive oxygen species (ROS) production, and DNA binding. Compound 52 exhibited disintegrated cell membranes and condensed cellular protein, probably due to the lipids and proteins' oxidation, suggesting that it could be a potent drug against cancer. Several Schiff bases of tetrahydrocurcumin have been recently reported by Mahal et al. (2019) [73] as potential anticancer agents. The in vitro anticancer activity was evaluated against three human cancer cell lines: human epithelial lung carcinoma (A549) and cervical cancer (HeLa) and human breast adenocarcinoma (MCF-7) cells. Most compounds exhibited moderate to good anticancer activity against all three tested cell lines and were significantly more active than tetrahydrocurcumin. The most interesting was compound $53\left(\mathrm{IC}_{50}=11.9,12.7,4.8 \mu \mathrm{M}\right.$, against the three cell lines considered, respectively). Erturk et al. (2020) [74] synthesized and studied two Schiff bases (54 and 55) for different biological activities, among them the antitumor one, against MCF-7 human breast cancer cell line. The $\mathrm{IC}_{50}$ values were 6.70 , 2.20 , and $<0.1 \mathrm{mM}$ for $54 ; 1.00,0.30$, and $0.14 \mathrm{mM}$ for 55 for 24,48 , and $72 \mathrm{~h}$, respectively. The higher activity of compound containing 10-chloroanthracene 55 than that containing 8-hydroxyquinoline 54 was in agreement with theoretical calculations obtained by various spectroscopic analyses and single-crystal X-ray diffraction and Hirshfeld surface analysis and fingerprint plots of the two compounds. Suyambulingam et al. (2020) [75] synthesized two Schiff bases (56 and 57) and evaluated their antiproliferative activity against MCF-7 cells, obtaining $\mathrm{IC}_{50}$ values of $80.19 \mu \mathrm{M}$ for compound 56 and $44.12 \mu \mathrm{M}$ for compound 57 (doxorubicin: $\mathrm{IC}_{50}=2.05 \mu \mathrm{M}$ ). Molecular docking studies were also carried out against six different active sites [76,77]. Mishra et al. (2020) [78] studied several Schiff bases containing a benzothiazole nucleus and studied the DNA binding interaction with pBR322 plasmid DNA by means of electrophoretic mobility shift assay [79]. The anticancer study was performed using the MTT assay. Imine 58 showed $85.82 \%$ inhibition of MCF-7 cancer cell lines at a concentration of $200 \mu \mathrm{g} / \mathrm{mL}$. It was less toxic to normal cells at the concentration required to produce the anticancer effect $\left(\mathrm{IC}_{50}=973 \mu \mathrm{g} / \mathrm{mL}\right)$.

Table 1. Mono-Schiff bases.
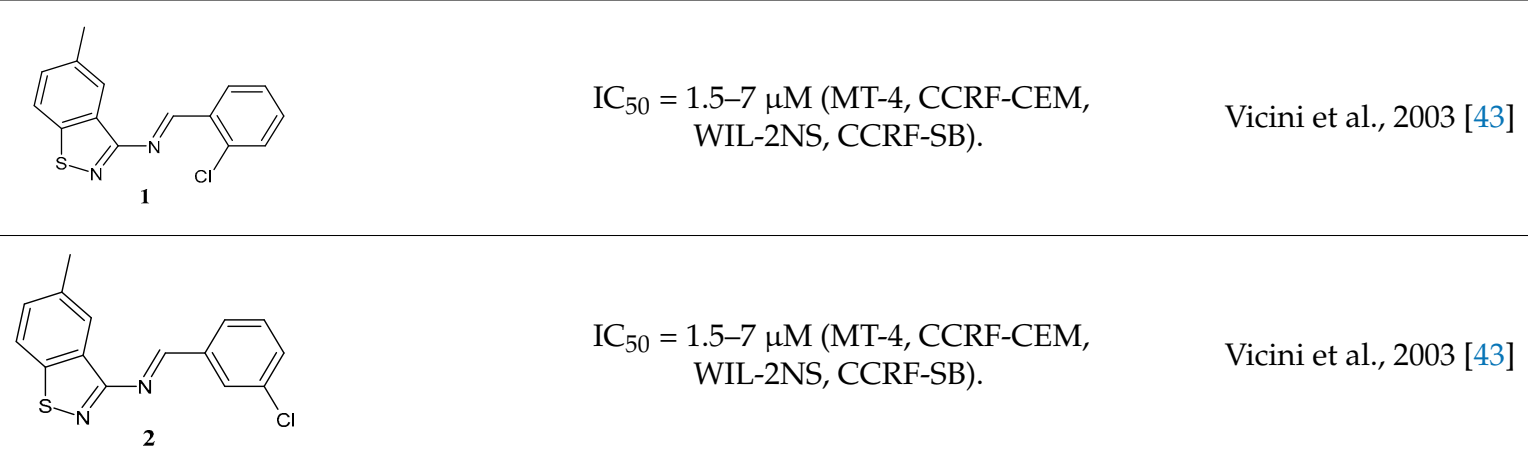

$$
\begin{aligned}
\mathrm{IC}_{50}= & 1.5-7 \mu \mathrm{M}(\mathrm{MT}-4, \mathrm{CCRF}-\mathrm{CEM}, \\
& \text { WIL-2NS, CCRF-SB). }
\end{aligned}
$$

Vicini et al., 2003 [43]

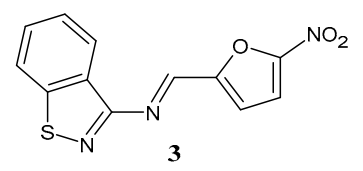

$$
\begin{gathered}
\mathrm{IC}_{50}=1.5-7 \mu \mathrm{M} \text { (MT-4, CCRF-CEM, } \\
\text { WIL-2NS, CCRF-SB). } \\
\mathrm{IC}_{50}=6 \mu \mathrm{M} \text { (SK-MEL-28). } \\
\mathrm{IC}_{50}=10 \mu \mathrm{M} \text { (MCF-7). }
\end{gathered}
$$


Table 1. Cont.

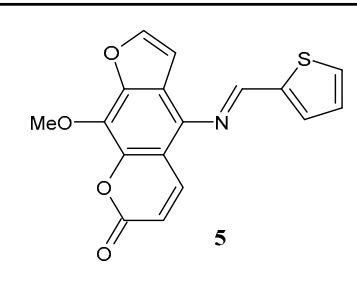

$$
\mathrm{IC}_{50}=7.2 \mu \mathrm{M}(\mathrm{HeLa})
$$

Abdel-Hafez et al., 2009 [45]

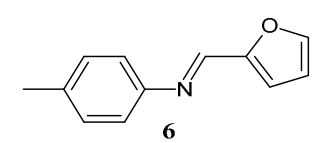

$$
\begin{gathered}
\mathrm{IC}_{50}=39.9 \mu \mathrm{M}(\mathrm{LAMA}-84), 29.9 \mu \mathrm{M} \\
(\mathrm{K}-562), 68.6 \mu \mathrm{M}(\mathrm{HL}-60 / \mathrm{Dox}) . \\
\mathrm{IC}_{50}>400 \mu \mathrm{M}(\mathrm{HL}-60) .
\end{gathered}
$$

Kraicheva et al., 2009 [46]

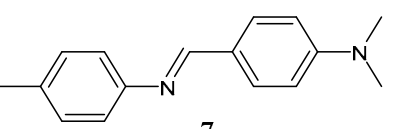

$\mathrm{IC}_{50}=251.9 \mu \mathrm{M}($ LAMA-84), $212.9 \mu \mathrm{M}$

(K-562), $226.1 \mu \mathrm{M}$ (HL-60/Dox).

$\mathrm{IC}_{50}>400 \mu \mathrm{M}$ (HL-60).

Kraicheva et al., 2009 [46]

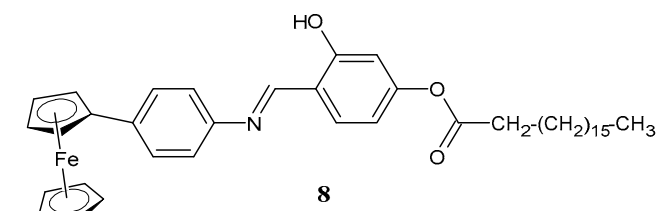

Tumor growth inhibition $=71 \%$;

$\mathrm{IC}_{50}=20 \mu \mathrm{g} / \mathrm{mL}$ (Potato disc tumor induction assay using $A$. tumefaciens

Nawaz et al., 2009 [47] (At-10).

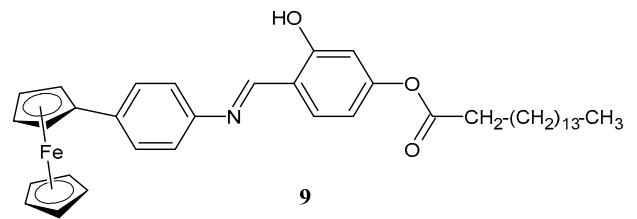

Tumor growth inhibition $=58 \%$; $\mathrm{IC}_{50}=563 \mu \mathrm{g} / \mathrm{mL}$ (Potato disc tumor induction assay using $A$. tumefaciens

Nawaz et al., 2009 [47] (At-10).

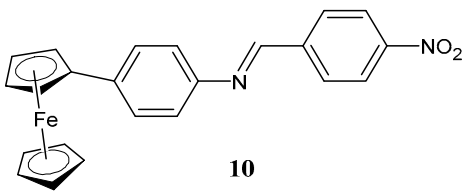

$$
\begin{gathered}
\mathrm{LD}_{50}=292.95 \text { ppm (brine shrimp } \\
\text { lethality assay). }
\end{gathered}
$$

Zaheer et al., 2010 [48]

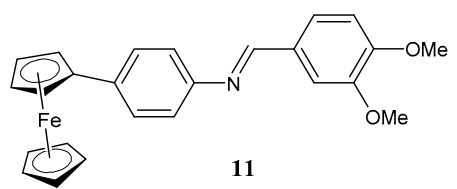

$$
\begin{gathered}
\mathrm{LD}_{50}=18.22 \mathrm{ppm} \text { (brine shrimp lethality } \\
\text { assay). }
\end{gathered}
$$

Zaheer et al., 2010 [48]

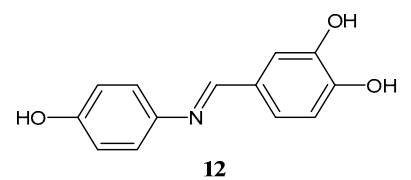

$$
\begin{gathered}
\mathrm{IC}_{50}=5.6 \mu \mathrm{M}(\text { HepG2). } \\
\mathrm{IC}_{50}=17.22 \mu \mathrm{M} \text { (murine B16F10 } \\
\text { melanoma cells). }
\end{gathered}
$$

Cheng et al., 2010 [49]

Bae et al., 2012 [55]

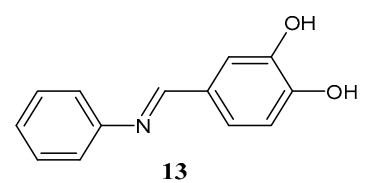

$$
\mathrm{IC}_{50}=6.8 \mu \mathrm{M}(\text { HepG2}) .
$$


Table 1. Cont.

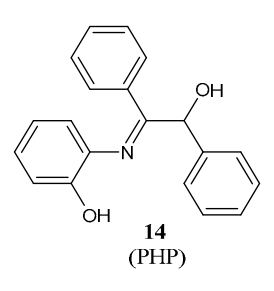

$$
\mathrm{LD}_{50}=16 \mathrm{mg} / \mathrm{kg} \text {. }
$$

Jesmin et al., 2010 [50]

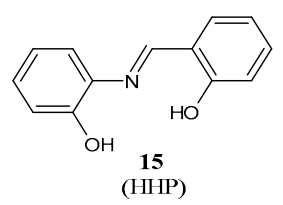

$\mathrm{LD}_{50}=15.5 \mathrm{mg} / \mathrm{kg}$; maximum

percentage cell growth inhibition $=93 \%$

(EAC).

Jesmin et al., 2010 [50]

(HHP)<smiles>C(=N/c1nc2ccccc2s1)\c1ccco1</smiles>

$\mathrm{IC}_{50}=0.186 \mu \mathrm{M}(\mathrm{HeLa})$.

Etaiw et al., 2011 [51]

16

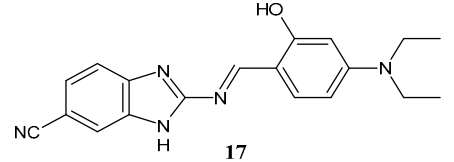

$\mathrm{IC}_{50}=4.73$ (HeLa), 9.23 (MCF-7, metastatic).

Hranjec et al., 2011 [52]

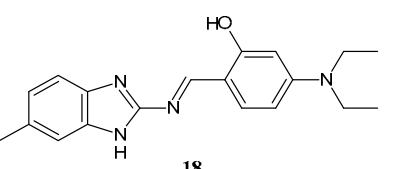

$\mathrm{IC}_{50}=3.24 \mu \mathrm{M}$ (HeLa), $15.27 \mu \mathrm{M}$ (MCF-7, metastatic).

Hranjec et al., 2011 [52]

18

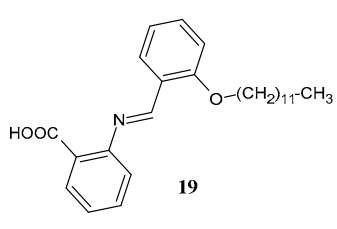

$\mathrm{IC}_{50}=1-10 \mathrm{mg} / \mathrm{mL}$ (HepG2, HCT-116 and MCF-7).

Shaker et al., 2011 [53]

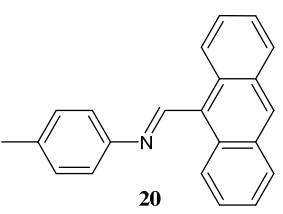

$\mathrm{IC}_{50}=0.08 \mathrm{mg} / \mathrm{mL}$ (HT-29 cell line)

Kraicheva et al., 2012 [54]

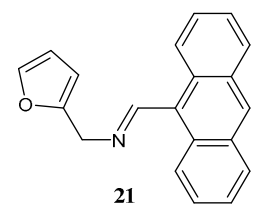

$\mathrm{IC}_{50}=0.20 \mathrm{mg} / \mathrm{mL}$ (HT-29 cell line).

Kraicheva et al., 2012 [54]

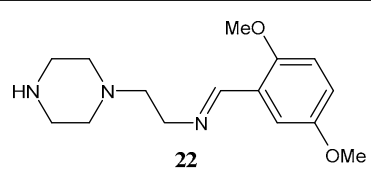

PG inhibition $=49 \%\left(\right.$ at $1 \times 10^{-5} \mathrm{M}$ against NCI H-522).

Sondhi et al., 2012 [56] 
Table 1. Cont.

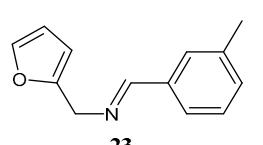

23
$\mathrm{IC}_{50}=50.12 \mu \mathrm{M}$ (KYSE 150), $158.49 \mu \mathrm{M}$

(KYSE30), $111.2 \mu \mathrm{M}$ (KYSE 270).
Klimczak et al., 2013 [57]

Hafez et al., 2013 [58]

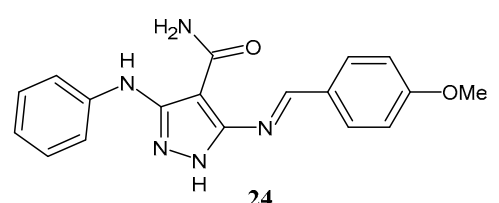

$\mathrm{IC}_{50}=0.44 \mu \mathrm{M}(\mathrm{SK}$ OV-3)

$\mathrm{IC}_{50}=0.09 \mathrm{nM}(\mathrm{U} 937), \mathrm{IC}_{50}=0.45 \mathrm{nM}$

(GOTO), $\mathrm{IC}_{50}=0.64 \mathrm{nM}(\mathrm{NB}-1)$,

$\mathrm{IC}_{50}=0.54 \mathrm{nM}(\mathrm{HT} 1080)$.
Hafez et al., 2013 [58]<smiles>NC(=O)c1c(Nc2ccccc2)n[nH]c1/N=C1/C2C=CC(C2)C12CCCC2</smiles>

$\mathrm{IC}_{50}=0.54 \mu \mathrm{M}(\mathrm{KB}), \mathrm{IC}_{50}=0.30 \mathrm{nM}$ (CNS, SF-268), $\mathrm{IC}_{50}=0.43 \mathrm{nM}(\mathrm{K}-562)$, $\mathrm{IC}_{50}=0.09 \mathrm{nM}(\mathrm{HepG} 2), \mathrm{IC}_{50}=6.60 \mathrm{nM}$ (NCI H460).

$\mathrm{IC}_{50}=6.20 \mu \mathrm{g} / \mathrm{mL}\left(\right.$ HepG2), $\mathrm{IC}_{50}=7$

$$
\mu \mathrm{g} / \mathrm{mL}(\mathrm{MCF}-7) .
$$

Hassan et al., 2015 [59]<smiles></smiles>

2<smiles>Cc1ccc(/C=N/c2nnc(SCc3csc(-c4ccccc4)n3)s2)cc1</smiles>

29<smiles>Oc1ccc(/C=N/c2nnc(SCc3coc(-c4ccccc4)n3)s2)c(O)c1</smiles><smiles>Oc1ccccc1/C=N/c1nnc(SCc2coc(-c3ccccc3)n2)s1</smiles>

31

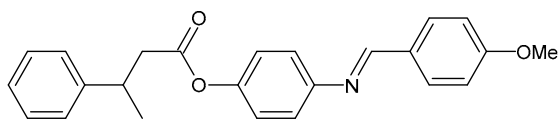

$\mathrm{IC}_{50}=4.02 \mu \mathrm{M}(\mathrm{MCF}-7)$.

Zhao et al., 2013 [60]

$\mathrm{IC}_{50}=7.55 \mu \mathrm{M}(\mathrm{MCF}-7)$.

Zhao et al., 2013 [60]

$\mathrm{IC}_{50}=8.51 \mu \mathrm{M}(\mathrm{MCF}-7)$.

Zhao et al., 2013 [60]

$\mathrm{IC}_{50}=38.73 \mu \mathrm{M}(\mathrm{L} 1210)$.

Zhao et al., 2013 [60] 
Table 1. Cont.

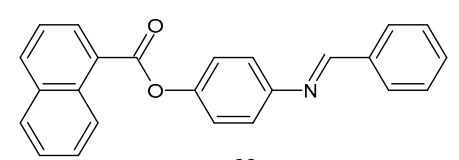

33

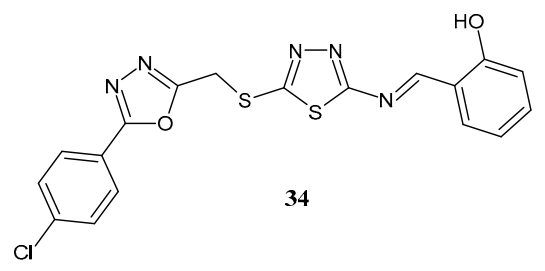

$\mathrm{IC}_{50}=2.84 \mu \mathrm{M}(\mathrm{SMMC}-7721)$.

$\mathrm{IC}_{50}=4.56 \mu \mathrm{M}(\mathrm{MCF}-7)$.

35

$\mathrm{MeO}$

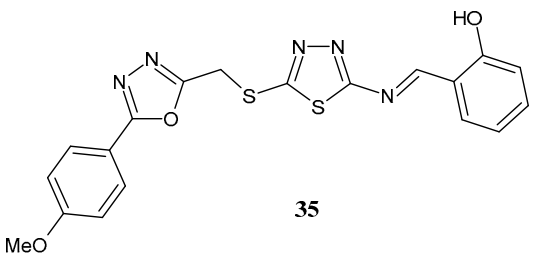

$\mathrm{IC}_{50}=8.03 \mu \mathrm{g} / \mathrm{mL}$ (potato disc).

Noureen et al., 2013 [61]

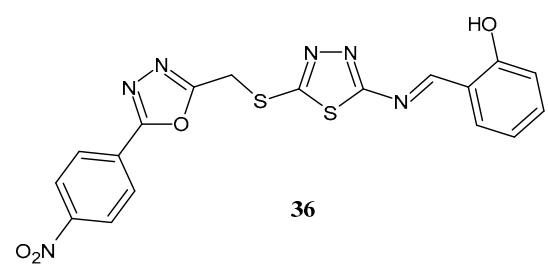

$\mathrm{IC}_{50}=4.25 \mu \mathrm{M}(\mathrm{MCF}-7), \mathrm{IC}_{50}=4.13 \mu \mathrm{M}$ (A549).

Zhang et al., 2014 [62]

Zhang et al., 2014 [62]

$\mathrm{IC}_{50}=4.11 \mu \mathrm{M}(\mathrm{A} 549)$.

Zhang et al., 2014 [62]

37

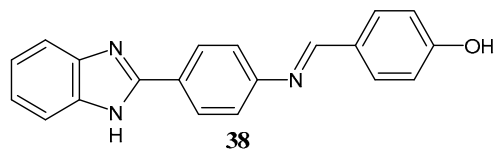

$\mathrm{IC}_{50}=4.83 \mu \mathrm{M}(\mathrm{PC} 3)$.

Gupta et al., 2015 [63]

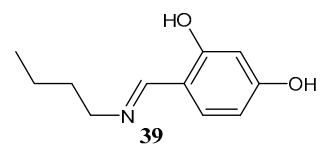

$\mathrm{IC}_{50}=7.43 \mu \mathrm{M}(\mathrm{PC} 3)$.

Gupta et al., 2015 [63]

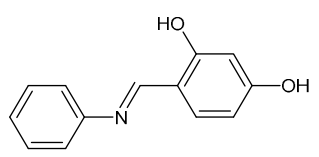

$\mathrm{IC}_{50}=7.15 \mu \mathrm{M}(\mathrm{PC} 3)$.

Gupta et al., 2015 [63]

40

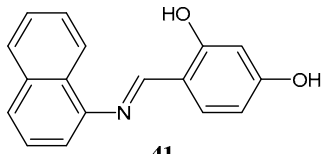

$\mathrm{IC}_{50}$ value of $0.02 \mu \mathrm{M}$ (Hsp90 ATPase suppression).
Zhang et al., 2014 [62] 
Table 1. Cont.

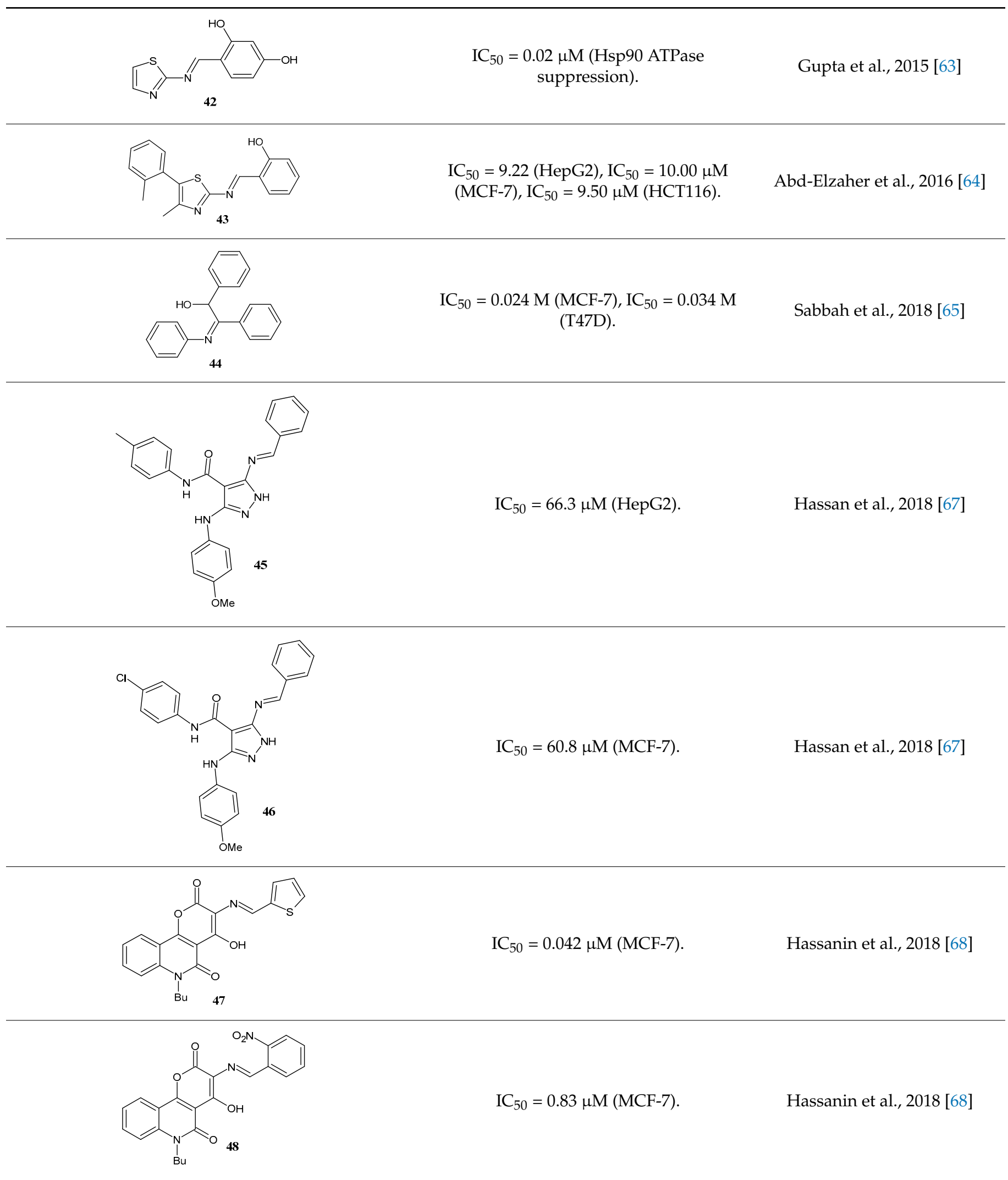


Table 1. Cont.
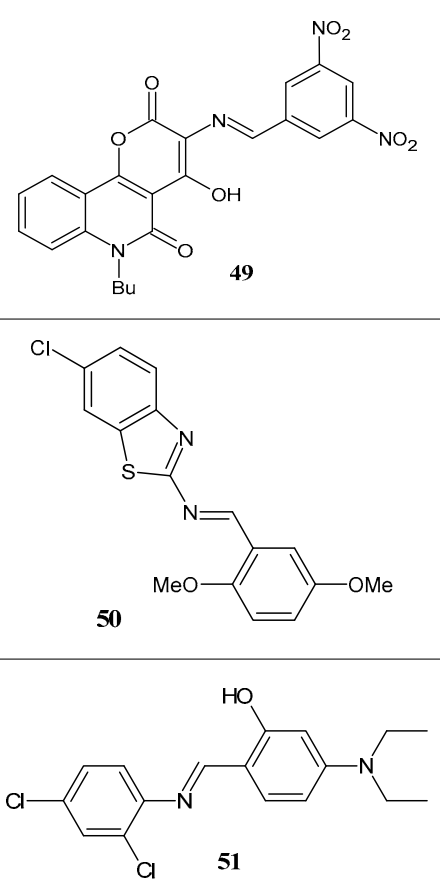

$\mathrm{IC}_{50}=56.7 \mu \mathrm{M}(\mathrm{HeLa}), \mathrm{IC}_{50}=32.2 \mu \mathrm{M}$ (BHK-21).

Uddin et al., 2019 [72]

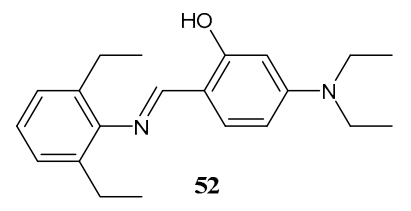

$\mathrm{IC}_{50}=20.8 \mu \mathrm{M}(\mathrm{HeLa}), \mathrm{IC}_{50}=60.2 \mu \mathrm{M}$ (BHK-21).

Uddin et al., 2019 [72]<smiles>COc1cc(CCN=C(CCc2ccc(C(F)(F)F)cc2)CC(=O)CCc2ccc(O)c(OC)c2)ccc1O</smiles>

$\mathrm{IC}_{50}=11.9 \mu \mathrm{M}(\mathrm{A} 549), \mathrm{IC}_{50}=12.7 \mu \mathrm{M}$

$(\mathrm{HeLa}), \mathrm{IC}_{50}=4.8 \mu \mathrm{M}(\mathrm{MCF}-7)$.

Mahal et al., 2019 [73]<smiles>Cc1c(/N=C/c2ccc3cccc(O)c3n2)c(=O)n(-c2ccccc2)n1C</smiles>

$\mathrm{IC}_{50}=6.70,2.20$, and $<0.1 \mathrm{mM}$ (for 24,48 and $72 \mathrm{~h}$ against MCF-7).

Erturk et al., 2020 [74]

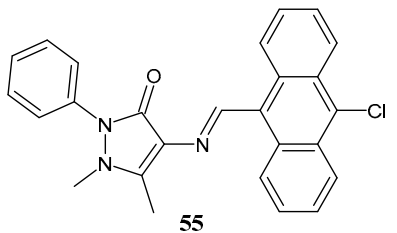

$\mathrm{IC}_{50}=1.00,0.30$ and $0.14 \mathrm{mM}$ (for 24, 48 and $72 \mathrm{~h}$ against MCF-7).

Erturk et al., 2020 [74]<smiles>Cc1ccc2nc(/N=C/c3ccccc3O)sc2c1</smiles>

$\mathrm{IC}_{50}=80.19 \mu \mathrm{M}(\mathrm{MCF}-7)$.

Suyambulingam et al., 2020

[75] 
Table 1. Cont

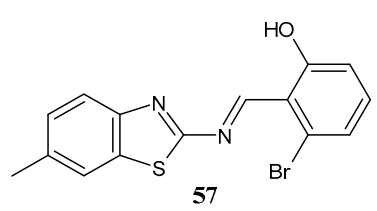

$\mathrm{IC}_{50}=44.12 \mu \mathrm{M}$ (MCF-7).

Suyambulingam et al., 2020

[75]

5

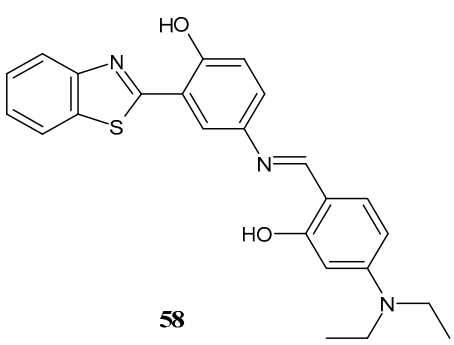

Percentage inhibition $=85.82 \%($ at $200 \mu \mathrm{g} / \mathrm{mL}$ against MCF-7).

Mishra et al., 2020 [78]

\subsection{Bis-Schiff Bases}

Desai et al. (2001) [80] reported a study on 10 Schiff bases and evaluated their antiproliferative activity by measuring their effect on the (PG) of 57 different cancer cell lines, including lung, colon, central nervous system (CNS), ovarian, renal, prostrate, melanoma, leukemia, and breast cancer. Compounds 59-62 (Table 2) showed activity against different cell lines. Particularly, compounds 59 and $\mathbf{6 0}$ were effective on leukemia (SR and MOLT-4) and colon (COLO-205), compound 62 on leukemia (SR and MOLT-4), CNS (SF-539) and melanoma (SK-MEL-28 and UACC-257). Against some of the abovementioned cell lines, other compounds have also been reported to be active, particularly, compound $\mathbf{6 1}$ on CNS, melanoma, and breast and compound 59 on leukemia, colon, and breast. Compound $\mathbf{6 0}$ was the most effective of imines analogues on leukemia. Padhye et al. (2009) [81] studied several Schiff bases and copper complexes as proteasome inhibitors and apoptosis inducers in human colon cancer HCT-116 cells, in comparison to curcumin. Among the synthesized compounds, the authors demonstrated that the fluorine-substituted curcumin analogs were superior to the curcumin against HCT-116 and BxPC-3 pancreatic cancer cells, probably because of the higher metabolic stability allowed by the fluoro substituents. Compound 63 showed approximately $80 \%, 60 \%$, and $60 \%$ proteasome inhibition at 10, 20, and $30 \mu \mathrm{M}$ (curcumin: $27 \%, 47 \%$, and $64 \%$ at 10,20 , and $30 \mu \mathrm{M}$, respectively). In the study by Sondhi et al. (2012) [56], described in the paragraph below, the activity of mono-Schiff bases and bis-Schiff bases was evaluated. Compound 64 showed activity against ovary (PA1) cancer cells (62\% versus $93 \%$ of actinomycin-D) and 65 against both breast (T47D) and ovary (PA1) $(41 \%$ and $53 \%$, respectively, versus $21 \%$ and $93 \%$ of actinomycin-D, respectively) cancer cells.

Shokrollahi et al. (2020) [82] recently studied four tetrahydrobenzothiazole-based Schiff bases and tested their cytotoxic activity against the human breast cancer (MCF-7) and hepatocellular liver carcinoma (HepG2) cell lines by MTT assay. The compounds showed cytotoxic activity against both cell lines in a concentration-dependent manner. Compound 66 was the most active against MCF-7 ( $\mathrm{IC}_{50}=7.75$ and $34.52 \mu \mathrm{M}$, at 24 and $48 \mathrm{~h}$, respectively) and HepG2 ( $\mathrm{IC}_{50}=3.01$ and $1.29 \mu \mathrm{M}$, at 24 and $48 \mathrm{~h}$, respectively). Morsy et al. (2021) [83] recently reported some selected bis-Schiff bases studied for their in vitro antiproliferative activity toward three human carcinoma HepG2 (liver), MCF-7 (breast), and RPE-1 (normal retina pigmented epithelium) cell lines using MTT assay. The results showed that compound $\mathbf{6 7}$ was found to be the active candidate against HepG2 $\left(\mathrm{IC}_{50}=84.2 \mu \mathrm{M}\right.$ versus $25.3 \mu \mathrm{M}$ of doxorubicin) and MCF-7 cells $\left(\mathrm{IC}_{50}=99.4 \mu \mathrm{M}\right.$ versus $20.9 \mu \mathrm{M}$ of doxorubicin), while compound 68 was found to be the most active of the series against RPE- 1 cells $\left(\mathrm{IC}_{50}=127.7 \mu \mathrm{M}\right.$ versus $19.1 \mu \mathrm{M}$ of doxorubicin). 
Table 2. Bis-Schiff bases.

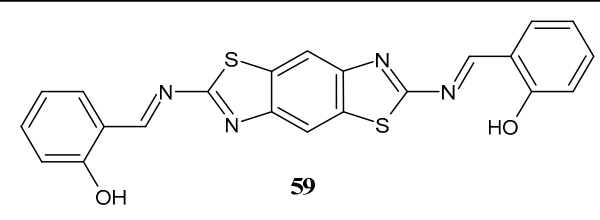

effective on leukemia (SR and MOLT-4), colon (COLO-205) and breast. IC $_{50}$ values not reported.

Desai et al., 2001 [80]<smiles>C(=C/c1ccccc1)\C=N\c1nc2cc3sc(/N=C/C=C/c4ccccc4)nc3cc2s1</smiles>

effective on leukemia (SR and MOLT-4), colon (COLO-205) and leukemia. $\mathrm{IC}_{50}$ values not reported.

Desai et al., 2001 [80]<smiles>COc1cc(/C=N/c2nc3cc4sc(/N=C/c5cc(OC)c(OC)c(OC)c5)nc4cc3s2)cc(OC)c1OC</smiles>

effective on CNS (SF-539),

melanoma (SK-MEL-28 and UACC-257) and breast. IC $_{50}$ values

Desai et al., 2001 [80] not reported.<smiles>CCOc1cc(/C=N/c2nc3cc4sc(/N=C/c5ccc(O)c(OCC)c5)nc4cc3s2)ccc1O</smiles>

effective on leukemia (SR and MOLT-4), CNS (SF-539), melanoma (SK-MEL-28 and UACC-257). IC $_{50}$ values not reported.

62<smiles>COc1cc(/N=C(\C=C\c2ccc(/C=C/c3ccc(F)c(F)c3)c(OC)c2)C(/C=C/c2ccc(O)c(F)c2)=N\c2ccc(F)c(F)c2)ccc1O</smiles>

proteasome inhibition: about $80 \%$, $60 \%$ and $60 \%$ at 10,20 and $30 \mu \mathrm{M}$.

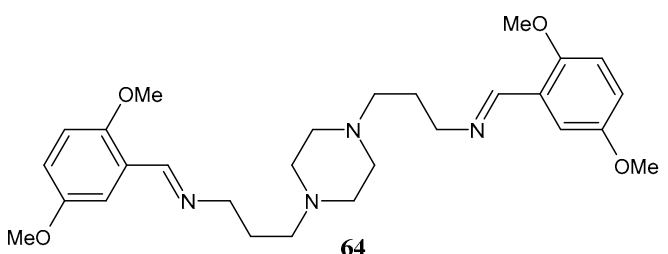

PG inhibition: 62\% (ovary, PA1).

Sondhi et al., 2012 [56]<smiles>COc1ccc(OC)c(/C=N/c2n[nH]c(/N=C/c3cc(OC)ccc3OC)n2)c1</smiles>

PG inhibition: 41\% (T47D) and 53\% (PA1).

Sondhi et al., 2012 [56]<smiles>Oc1ccc2ccccc2c1/C=N/c1nc2c(s1)CC(/N=C/c1c(O)ccc3ccccc13)CC2</smiles>

$\mathrm{IC}_{50}=7.75$ and $34.52 \mu \mathrm{M}$, at 24 and $48 \mathrm{~h}$, against MCF-7), $\mathrm{IC}_{50}=3.01$ and $1.29 \mu \mathrm{M}$, at 24 and $48 \mathrm{~h}$, against Shrollaki et al., 2020 [82] 
Table 2. Cont.
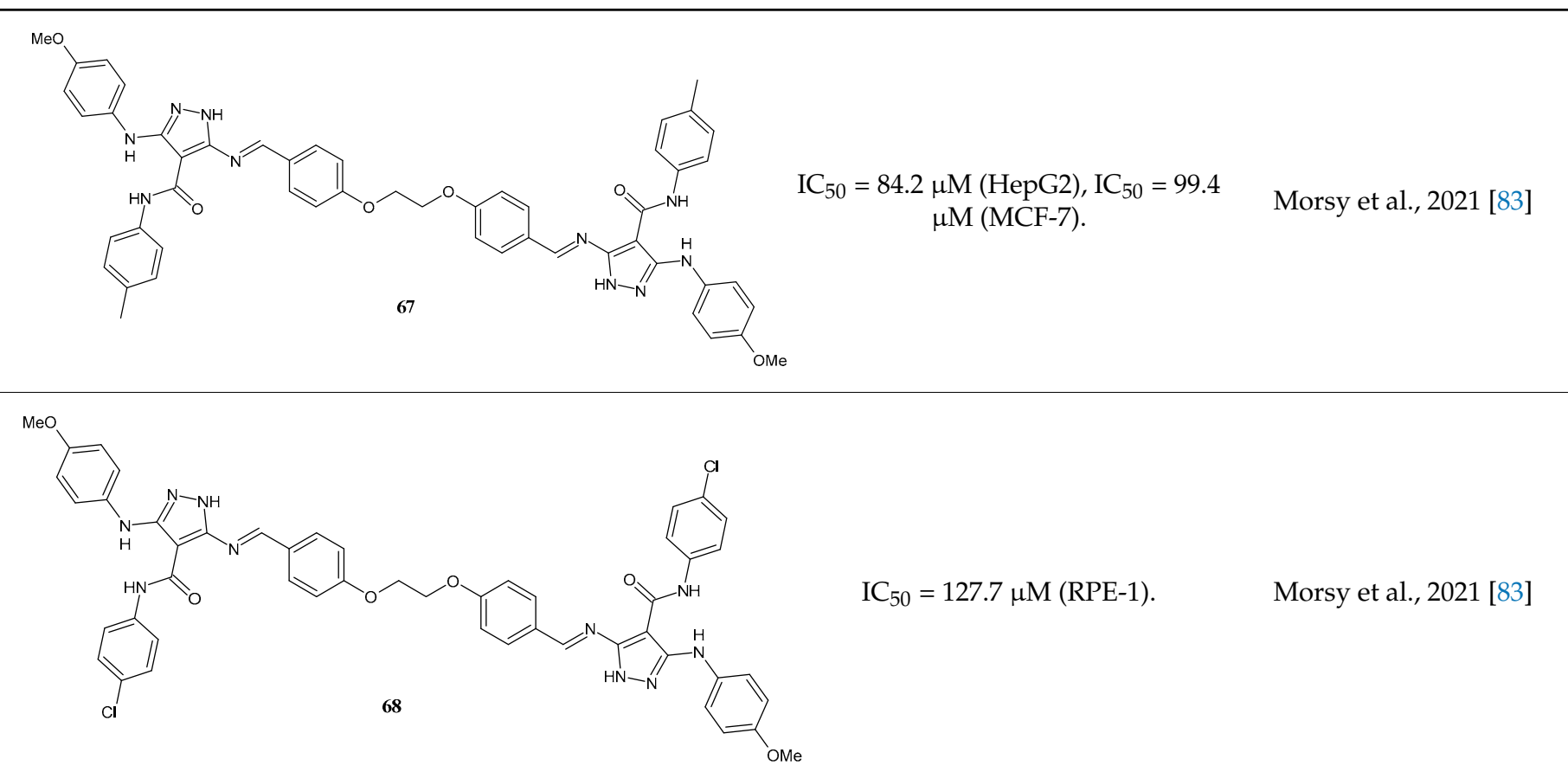

$\mathrm{IC}_{50}=127.7 \mu \mathrm{M}(\mathrm{RPE}-1)$.

Morsy et al., 2021 [83]

\section{Summary}

Schiff bases have long attracted researchers due to their chemical reactivity and to the broad range of pharmacological activities that they exert as such or complexed with metals, including antibacterial, antifungal, anti-inflammatory, antioxidant, and anticancer. They are also employed as versatile tools in several applications such as fluorescent turn-on/turn-off sensors for the determination of diverse analytes. Their easy preparation and capability of forming complexes with almost all metals make them interesting compounds in medicinal chemistry. Recently, several organic compounds bearing Schiff base structure or their complexes with metals were used as effective drugs against cancer. Metal complexes' actions are multiple, depending on the broad range of coordination numbers, geometries, and kinetic properties and, after the worldwide use of cisplatin, different papers reported the importance of Schiff bases' anticancer actions in metal complexes. The reviewed paper indicated that the use of these compounds offered better anticancer properties with respect to the reference molecules, viz., cisplatin, doxorubicin, and vincristine, for instance, both in in vitro and in vivo. It is worthy to note that these compounds displayed the anticancer effects against a very broad variety of tumor cell models, solid or liquid, without hampering, in the most cases, the growth of the normal cells used as control. Furthermore, Schiff bases may target different intracellular regulator enzymes, together with the already known interactions with nuclear DNA, producing cancer cells' death by apoptosis. Finally, different evidence about their ability to modulate the intracellular redox equilibrium, strongly associated with tumor prevention, onset, and progression, have been revealed, confirming the multiple actions exerted by these molecules. In this review, studies regarding mono- and bis-Schiff bases with potent antitumor activity on several cell lines were reviewed. In the future, the study of structure-activity relationships of Schiff bases against cancer cells may help in synthesizing new and effective antitumor agents derived by modification of the already studied imines.

Funding: No financial support.

Institutional Review Board Statement: Not applicable.

Informed Consent Statement: Not applicable. 
Conflicts of Interest: The authors declare no conflict of interest.

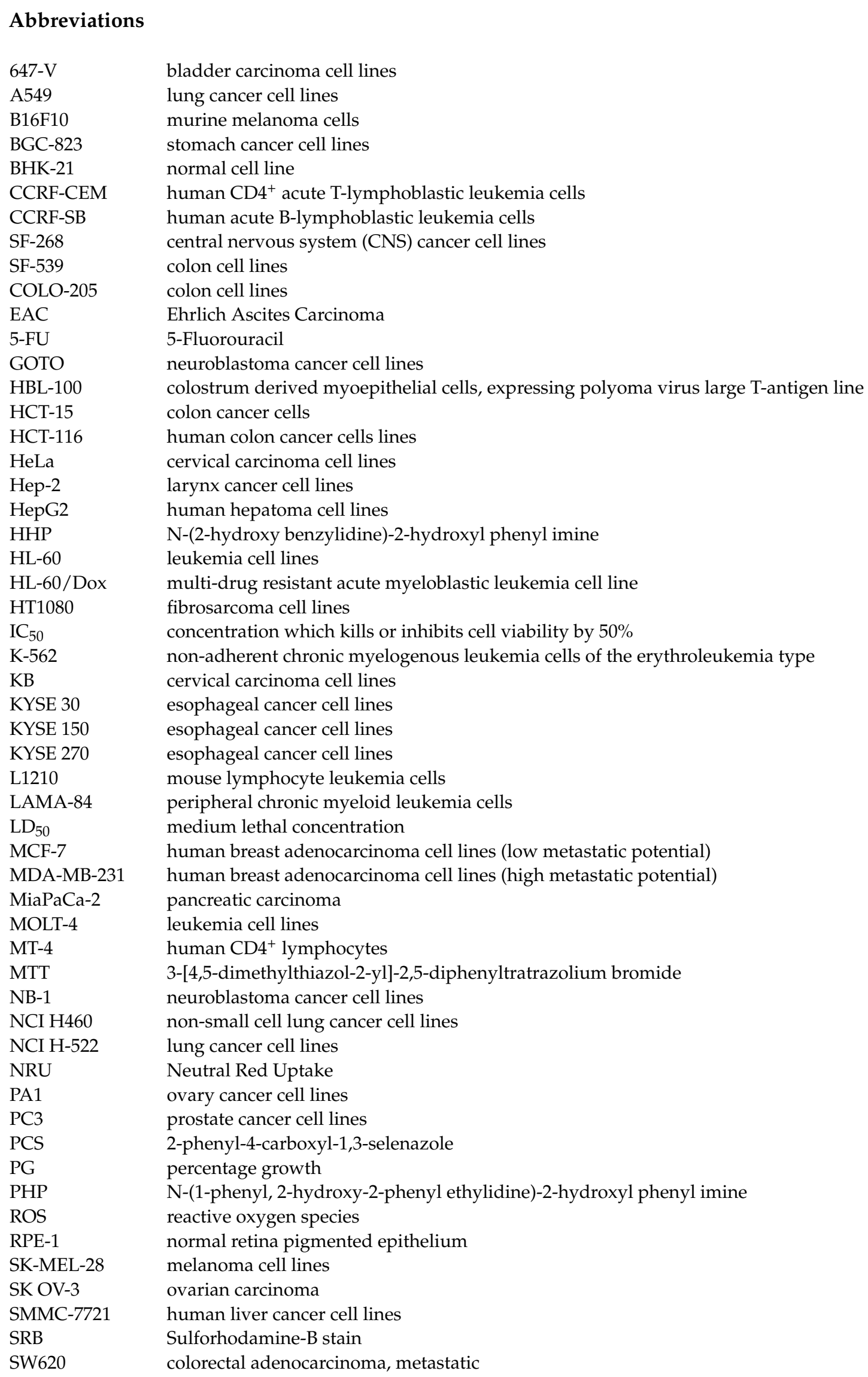


T47D breast cancer cell lines

U937 leukemia cell lines

UACC-257 melanoma cell lines

WIL-2NS human splenic B-lymphoblastoid cells

WST-8 2-(2-methoxy-4-nitrophenyl)-3-(4-nitrophenyl)-5-(2,4-disulfophenyl)-2H-tetrazolium monosodium salt

\section{References}

1. Qin, W.; Long, S.; Panunzio, M.; Biondi, S. Schiff bases: A short survey on an evergreen chemistry tool. Molecules 2013, 18, 12264-12289. [CrossRef] [PubMed]

2. Hameed, A.; al-Rashida, M.; Uroos, M.; Ali, S.A.; Khan, K.M. Schiff bases in medicinal chemistry: A patent review (2010-2015). Expert Opin. Ther. Pat. 2017, 27, 63-79. [CrossRef] [PubMed]

3. Murtaza, G.; Mumtaz, A.; Khan, F.A.; Ahmad, S.; Azhar, S.; Najam-Ul-Haq, M.; Atif, M.; Khan, S.A.; Maalik, A.; Alam, F.; et al. Recent pharmacological advancements in schiff bases: A review. Acta Pol. Pharm. 2014, 71, 531-535. [PubMed]

4. da Silva, C.M.; da Silva, D.L.; Modolo, L.V.; Alves, R.B.; de Resende, M.A.; Martins, C.V.; de Fatima, A. Schiff bases: A short review of their antimicrobial activities. J. Adv. Res. 2011, 2, 1-8. [CrossRef]

5. de Fátima, Â.; de Paula Pereira, C.; Olímpio, C.R.; de Freitas Oliveira, B.G.; Franco, L.L.; da Silva, P.H. Schiff bases and their metal complexes as urease inhibitors-a brief review. J. Adv. Res. 2018, 13, 113-126. [CrossRef]

6. Kajal, A.; Bala, S.; Kamboj, S.; Sharma, N.; Saini, V. Schiff bases: A versatile pharmacophore. J. Catal. 2013, 2013, 893512. [CrossRef]

7. Pandey, A.; Dewangan, D.; Verma, S.; Mishra, A.; Dubey, R.D. Synthesis of Schiff bases of 2-amino-5-aryl-1, 3,4-thiadiazole and its analgesic, anti-inflammatory, antibacterial and antitubercular activity. Int. J. Chem. Tech. Res. 2011, 3, 178-184.

8. Alafeefy, A.M.; Bakht, M.A.; Ganaie, M.A.; Ansarie, M.N.; El-Sayed, N.N.; Awaad, A.S. Synthesis, analgesic, anti-inflammatory and anti-ulcerogenic activities of certain novel Schiff's bases as fenamate isosteres. Bioorg. Med. Chem. Lett. 2015, 25, 179-183. [CrossRef]

9. Kumar, M.; Padmini, T.; Ponnuvel, K. Synthesis, characterization and antioxidant activities of Schiff bases are of cholesterol. J. Saudi Chem. Soc. 2017, 21, S322-S328. [CrossRef]

10. Teran, R.; Guevara, R.; Mora, J.; Dobronski, L.; Barreiro-Costa, O.; Beske, T.; Pérez-Barrera, J.; Araya-Maturana, R.; Rojas-Silva, P.; Poveda, A.; et al. Characterization of antimicrobial, antioxidant, and leishmanicidal activities of schiff base derivatives of 4-aminoantipyrine. Molecules 2019, 24, 2696. [CrossRef]

11. Shah, S.S.; Shah, D.; Khan, I.; Ahmad, S.; Ali, U.; ur Rahman, A. Synthesis and Antioxidant Activities of Schiff Bases and Their Complexes: An Updated Review. Biointerf. Res. Appl. Chem. 2020, 10, 6936-6963.

12. Zehra, S.; Shavez Khan, M.; Ahmad, I.; Arjmand, F. New tailored substituted benzothiazole Schiff base Cu(II)/Zn(II) antitumor drug entities: Effect of substituents on DNA binding profile, antimicrobial and cytotoxic activity. J. Biomol. Struct. Dynam. 2019, 37, 1863-1879. [CrossRef]

13. Utreja, D.V.; Singh, S.; Kaur, M. Schiff bases and their metal complexes as anti-cancer agents: A review. Curr. Bioact. Compd. 2015, 11, 215-230. [CrossRef]

14. Sztanke, K.; Maziarka, A.; Osinka, A.; Sztanke, M. An insight into synthetic Schiff bases revealing antiproliferative activities in vitro. Bioorg. Med. Chem. 2013, 21, 3648-3666. [CrossRef]

15. Demirci, S.; Doğan, A.; Başak, N.; Telci, D.; Dede, B.; Orhan, C.; Tuzcu, M.; Şahin, K.; Şahin, N.; Özercan, I.H.; et al. A Schiff base derivative for effective treatment of diethylnitrosamine-induced liver cancer in vivo. Anti-Cancer Drugs 2015, 26, 555-564. [CrossRef] [PubMed]

16. Berhanu, A.L.; Mohiuddin, I.; Malik, A.K.; Aulakh, J.S.; Kumar, V.; Kim, K.-H. A review of the applications of Schiff bases as optical chemical sensors. TrAC Trends Anal. Chem. 2019, 116, 74-91. [CrossRef]

17. Nourifard, F.; Payehghadr, M. Conductometric studies and application of new Schiff base ligand as carbon paste electrode modifier for mercury and cadmium determination. Int. J. Environ. Anal. Chem. 2016, 96, 552-567. [CrossRef]

18. Rahimi, M.; Amini, A.; Behmadi, H. Novel symmetric Schiff-base benzobisthiazole-salicylidene derivative with fluorescence turn-on behavior for detecting $\mathrm{Pb}^{2+}$ ion. J. Photochem. Photobiol. A Chem. 2020, 388, 112190. [CrossRef]

19. Gupta, V.K.; Singh, A.K.; Gupta, B. A cerium(III) selective polyvinyl chloride membrane sensor based on a Schiff base complex of N,N'-bis[2-(salicylideneamino)ethyl]ethane-1,2-diamine. Anal. Chim. Acta 2006, 575, 198-204. [CrossRef] [PubMed]

20. Milosavljevic, V.; Haddad, Y.; Merlos Rodrigo, M.A.; Moulick, A.; Polanska, H.; Hynek, D.; Hegel, Z.; Kopel, P.; Adam, V. The zinc-schiff base-novicidin complex as a potential prostate cancer therapy. PLoS ONE 2016, 11, e0163983. [CrossRef]

21. Catalano, A.; Iacopetta, D.; Pellegrino, M.; Aquaro, S.; Franchini, C.; Sinicropi, M.S. Diarylureas: Repositioning from Antitumor to Antimicrobials or Multi-Target Agents against New Pandemics. Antibiotics 2021, 10, 92. [CrossRef] [PubMed]

22. Abu-Dief, A.M.; Mohamed, I.M. A review on versatile applications of transition metal complexes incorporating Schiff bases. Beni-Suef Univ. J. Basic Appl. Sci. 2015, 4, 119-133.

23. Ghosh, P.; Dey, S.; Ara, M.; Karim, K.; Islam, A.B. A review on synthesis and versatile applications of some selected Schiff bases with their transition metal complexes. Egypt. J. Chem. 2020, 63, 5-6. [CrossRef]

24. Sakthivel, A.; Jeyasubramanian, K.; Thangagiri, B.; Raja, J.D. Recent advances in Schiff base metal complexes derived from 4-amoniantipyrine derivatives and their potential applications. J. Mol. Struct. 2020, 1222, 128885. [CrossRef] 
25. Saturnino, C.; Barone, I.; Iacopetta, D.; Mariconda, A.; Sinicropi, M.S.; Rosano, C.; Campana, A.; Catalano, S.; Longo, P.; Ando, S. $\mathrm{N}$-heterocyclic carbene complexes of silver and gold as novel tools against breast cancer progression. Future Med. Chem. 2016, 8 , 2213-2229. [CrossRef]

26. Chimento, A.; Saturnino, C.; Iacopetta, D.; Mazzotta, R.; Caruso, A.; Plutino, M.R.; Mariconda, A.; Ramunno, A.; Sinicropi, M.S.; Pezzi, V.; et al. Inhibition of human topoisomerase I and II and anti-proliferative effects on MCF-7 cells by new titanocene complexes. Bioorg. Med. Chem. 2015, 23, 7302-7312. [CrossRef]

27. Iacopetta, D.; Mariconda, A.; Saturnino, C.; Caruso, A.; Palma, G.; Ceramella, J.; Muia, N.; Perri, M.; Sinicropi, M.S.; Caroleo, M.C.; et al. Novel gold and silver carbene complexes exert antitumor effects triggering the reactive oxygen species dependent intrinsic apoptotic pathway. ChemMedChem 2017, 12, 2054-2065. [CrossRef]

28. Sirignano, E.; Saturnino, C.; Botta, A.; Sinicropi, M.S.; Caruso, A.; Pisano, A.; Lappano, R.; Maggiolini, M.; Longo, P. Synthesis, characterization and cytotoxic activity on breast cancer cells of new half-titanocene derivatives. Bioorg. Med. Chem. Lett. 2013, 23, 3458-3462. [CrossRef]

29. Ceramella, J.; Mariconda, A.; Iacopetta, D.; Saturnino, C.; Barbarossa, A.; Caruso, A.; Rosano, C.; Sinicropi, M.S.; Longo, P. From coins to cancer therapy: Gold, silver and copper complexes targeting human topoisomerases. Bioorg. Med. Chem. Lett. 2020, 30, 126905. [CrossRef] [PubMed]

30. Iacopetta, D.; Rosano, C.; Sirignano, M.; Mariconda, A.; Ceramella, J.; Ponassi, M.; Saturnino, C.; Sinicropi, M.S.; Longo, P. Is the way to fight cancer paved with gold? Metal-based carbene complexes with multiple and fascinating biological features. Pharmaceuticals 2020, 13, 91. [CrossRef]

31. Matela, G. Schiff Bases and Complexes: A Review on Anti-Cancer Activity. Anti-Cancer Agents Med. Chem. Former. Curr. Med. Chem. Anti-Cancer Agents 2020, 20, 1908-1917. [CrossRef]

32. Hodnett, E.M.; Mooney, P.D. Antitumor activities of some Schiff bases. J. Med. Chem. 1970, 13, 786. [CrossRef]

33. Hodnett, E.M.; Dunn, W.J. Structure-antitumor activity correlation of some Schiff bases. J. Med. Chem. 1970, 13, 768-770. [CrossRef]

34. Iacopetta, D.; Lappano, R.; Mariconda, A.; Ceramella, J.; Sinicropi, M.S.; Saturnino, C.; Talia, M.; Cirillo, F.; Martinelli, F.; Puoci, F. Newly synthesized imino-derivatives analogues of resveratrol exert inhibitory effects in breast tumor cells. Int. J. Mol. Sci. 2020, 21, 7797. [CrossRef]

35. Catalano, A.; Iacopetta, D.; Sinicropi, M.S.; Franchini, C. Diarylureas as Antitumor Agents. Appl. Sci. 2021, 11, 374. [CrossRef]

36. Sinicropi, M.S.; Caruso, A.; Conforti, F.; Marrelli, M.; El Kashef, H.; Lancelot, J.C.; Rault, S.; Statti, G.A.; Menichini, F. Synthesis, inhibition of no production and antiproliferative activities of some indole derivatives. J. Enzym. Inhib. Med. Chem. 2009, 24, 1148-1153. [CrossRef] [PubMed]

37. Iacopetta, D.; Catalano, A.; Ceramella, J.; Barbarossa, A.; Carocci, A.; Fazio, A.; La Torre, C.; Caruso, A.; Ponassi, M.; Rosano, C.; et al. Synthesis, anticancer and antioxidant properties of new indole and pyranoindole derivatives. Bioorg. Chem. 2020, 105, 104440. [CrossRef] [PubMed]

38. Sinicropi, M.S.; Iacopetta, D.; Rosano, C.; Randino, R.; Caruso, A.; Saturnino, C.; Muia, N.; Ceramella, J.; Puoci, F.; Rodriquez, M.; et al. N-thioalkylcarbazoles derivatives as new anti-proliferative agents: Synthesis, characterisation and molecular mechanism evaluation. J. Enzym. Inhib. Med. Chem. 2018, 33, 434-444. [CrossRef]

39. Iacopetta, D.; Carocci, A.; Sinicropi, M.S.; Catalano, A.; Lentini, G.; Ceramella, J.; Curcio, R.; Caroleo, M.C. Old Drug Scaffold, New Activity: Thalidomide-Correlated Compounds Exert Different Effects on Breast Cancer Cell Growth and Progression. ChemMedChem 2017, 12, 381-389. [CrossRef]

40. Filosa, R.; Peduto, A.; de Caprariis, P.; Saturnino, C.; Festa, M.; Petrella, A.; Pau, A.; Pinna, G.A.; Colla, P.L.; Busonera, B.; et al. Synthesis and antiproliferative properties of N3/8-disubstituted-3,8-diazabicyclo[3.2.1] octane analogues of 3,8-bis[2-(3,4,5trimethoxyphenyl)pyridin-4-yl]methyl-piperazine. Eur. J. Med. Chem. 2007, 42, 293-306. [CrossRef] [PubMed]

41. Ceramella, J.; Caruso, A.; Occhiuzzi, M.A.; Iacopetta, D.; Barbarossa, A.; Rizzuti, B.; Dallemagne, P.; Rault, S.; El-Kashef, H.; Saturnino, C.; et al. Benzothienoquinazolinones as new multi-target scaffolds: Dual inhibition of human Topoisomerase I and tubulin polymerization. Eur. J. Med. Chem. 2019, 181, 111583. [CrossRef] [PubMed]

42. Chen, S.; Liu, X.; Ge, X.; Wang, Q.; Xie, Y.; Hao, Y.; Zhang, Y.; Zhang, L.; Shang, W.; Liu, Z. Lysosome-targeted iridium(III) compounds with pyridine-triphenylamine Schiff base ligands: Syntheses, antitumor applications and mechanisms. Inorg. Chem. Front. 2020, 7, 91-100. [CrossRef]

43. Vicini, P.; Geronikaki, A.; Incerti, M.; Busonera, B.; Poni, G.; Kabras, C.A.; Colla, P.L. Synthesis and biological evaluation of benzo[d]isothiazole, benzothiazole and thiazole Schiff bases. Bioorg. Med. Chem. 2003, 11, 4785-4789. [CrossRef]

44. Zhou, X.; Shao, L.; Jin, Z.; Liu, J.-B.; Dai, H.; Fang, J.-X. Synthesis and antitumor activity evaluation of some Schiff bases derived from 2-aminothiazole derivatives. Heteroat. Chem. 2007, 18, 55-59. [CrossRef]

45. Abdel-Hafez, O.M.; Amin, K.M.; Abdel-Latif, N.A.; Mohamed, T.K.; Ahmed, E.Y.; Maher, T. Synthesis and antitumor activity of some new xanthotoxin derivatives. Eur. J. Med. Chem. 2009, 44, 2967-2974. [CrossRef] [PubMed]

46. Kraicheva, I.; Bogomilova, A.; Tsacheva, I.; Momekov, G.; Troev, K. Synthesis, NMR characterization and in vitro antitumor evaluation of new aminophosphonic acid diesters. Eur. J. Med. Chem. 2009, 44, 3363-3367. [CrossRef] [PubMed]

47. Nawaz, H.; Akhter, Z.; Yameen, S.; Siddiqi, H.M.; Mirza, B.; Rifat, A. Synthesis and biological evaluations of some Schiff-base esters of ferrocenyl aniline and simple aniline. J. Organomet. Chem. 2009, 694, 2198-2203. [CrossRef] 
48. Zaheer, M.; Shah, A.; Akhter, Z.; Qureshi, R.; Mirza, B.; Tauseef, M.; Bolte, M. Synthesis, characterization, electrochemistry and evaluation of biological activities of some ferrocenyl Schiff bases. Appl. Organomet. Chem. 2011, 25, 61-69. [CrossRef]

49. Cheng, L.; Tang, J.; Luo, H.; Jin, X.; Dai, F.; Yang, J.; Qian, Y.; Li, X.; Zhou, B. Antioxidant and antiproliferative activities of hydroxyl-substituted Schiff bases. Bioorg. Med. Chem. Lett. 2010, 20, 2417-2420. [CrossRef]

50. Jesmin, M.; Ali, M.M.; Khanam, J.A. Antitumour activities of some Schiff bases derived from benzoin, salicylaldehyde, aminophenol and 2,4-dinitrophenyl hydrazine. Thai. J. Pharm. Sci. 2010, 34, 20-31.

51. Etaiw, S.E.; Abd El-Aziz, D.M.; Abd El-Zaher, E.H.; Ali, E.A. Synthesis, spectral, antimicrobial and antitumor assessment of Schiff base derived from 2-aminobenzothiazole and its transition metal complexes. Spectrochim. Acta A Mol. Biomol. Spectrosc. 2011, 79, 1331-1337. [CrossRef]

52. Hranjec, M.; Starčević, K.; Pavelić, S.K.; Lučin, P.; Pavelić, K.; Zamola, G.K. Synthesis, spectroscopic characterization and antiproliferative evaluation in vitro of novel Schiff bases related to benzimidazoles. Eur. J. Med. Chem. 2011, 46, 2274-2279. [CrossRef]

53. Shaker, N.O.; Abd El-Salam, F.H.; El-Sadek, B.M.; Kandeel, E.M.; Baker, S.A. Anionic Schiff base amphiphiles: Synthesis, surface, biocidal and antitumor activities. J. Am. Sci. 2011, 7, 427-436.

54. Kraicheva, I.; Tsacheva, I.; Vodenicharova, E.; Tashev, E.; Tosheva, T.; Kril, A.; Topashka-Ancheva, M.; Iliev, I.; Gerasimova, T.; Troev, K. Synthesis, antiproliferative activity and genotoxicity of novel anthracene-containing aminophosphonates and a new anthracene-derived Schiff base. Bioorg. Med. Chem. 2012, 20, 117-124. [CrossRef]

55. Bae, S.J.; Ha, Y.M.; Park, Y.J.; Park, J.Y.; Song, Y.M.; Ha, T.K.; Chun, P.; Moon, H.; Chung, H.Y. Design, synthesis, and evaluation of (E)-N-substituted benzylidene-aniline derivatives as tyrosinase inhibitors. Eur. J. Med. Chem. 2012, 57, 383-390. [CrossRef]

56. Sondhi, S.M.; Arya, S.; Rani, R.; Kumar, N.; Roy, P. Synthesis, anti-inflammatory and anticancer activity evaluation of some monoand bis-Schiff's bases. Med. Chem. Res. 2012, 21, 3620-3628. [CrossRef]

57. Klimczak, A.A.; Kuropatwa, A.; Lewkowski, J.; Szemraj, J. Synthesis of new N-arylamino (2-furyl) methylphosphonic acid diesters, and in vitro evaluation of their cytotoxicity against esophageal cancer cells. Med. Chem. Res. 2013, 22, 852-860. [CrossRef]

58. Hafez, T.S.; Osman, S.A.; Yosef, H.A.; Abd El-All, A.S.; Hassan, A.S.; El-Sawy, A.A.; Abdallah, M.M.; Youns, M. Synthesis, structural elucidation and in vitro antitumor activities of some pyrazolopyrimidines and Schiff Bases derived from 5-amino-3(arylamino)-1H-pyrazole-4-carboxamides. Sci. Pharm. 2013, 81, 339-357. [CrossRef]

59. Hassan, A.S.; Hafez, T.S.; Osman, S.A.; Ali, M.M. Synthesis and in vitro cytotoxic activity of novel pyrazolo[1,5-a]pyrimidines and related Schiff bases. Turk. J. Chem. 2015, 39, 1102-1113. [CrossRef]

60. Zhao, H.C.; Shi, Y.P.; Liu, Y.M.; Li, C.W.; Xuan, L.N.; Wang, P.; Zhang, K.; Chen, B.Q. Synthesis and antitumor-evaluation of 1, 3-selenazole-containing 1, 3, 4-thiadiazole derivatives. Bioorg. Med. Chem. Lett. 2013, 23, 6577-6579. [CrossRef] [PubMed]

61. Noureen, A.; Saleem, S.; Fatima, T.; Siddiqi, H.M.; Mirza, B. Synthesis, characterization, biological evaluation and QSAR of some Schiff base esters: Promising new antitumor, antioxidant and anti-inflammatory agents. Pak. J. Pharm. Sci. 2013, 26, 113-124.

62. Zhang, K.; Wang, P.; Xuan, L.-N.; Fu, X.-Y.; Jing, F.; Li, S.; Liu, Y.-M.; Chen, B.-Q. Synthesis and antitumor activities of novel hybrid molecules containing 1,3,4-oxadiazole and 1,3,4-thiadiazole bearing Schiff base moiety. Bioorg. Med. Chem. Lett. 2014, 24, 5154-5156. [CrossRef] [PubMed]

63. Gupta, S.D.; Revathi, B.; Mazaira, G.I.; Galigniana, M.D.; Subrahmanyam, C.V.; Gowrishankar, N.L.; Raghavendra, N.M. 2,4dihydroxy benzaldehyde derived Schiff bases as small molecule Hsp90 inhibitors: Rational identification of a new anticancer lead. Bioorg. Chem. 2015, 59, 97-105. [CrossRef]

64. Abd-Elzaher, M.M.; Labib, A.A.; Mousa, H.A.; Moustafa, S.A.; Ali, M.M.; El-Rashedy, A.A. Synthesis, anticancer activity and molecular docking study of Schiff base complexes containing thiazole moiety. Beni Suef Univ. J. Basic. Appl. Sci. 2016, 5, 85-96. [CrossRef]

65. Sabbah, D.A.; Al-Tarawneh, F.; Talib, W.H.; Sweidan, K.; Bardaweel, S.K.; Al-Shalabi, E.; Zhong, H.A.; Abu Sheikha, G.; Abu Khalaf, R.; Mubarak, M.S. Benzoin schiff bases: Design, synthesis, and biological evaluation as potential antitumor agents. Med. Chem. 2018, 14, 695-708. [CrossRef] [PubMed]

66. Perri, A.M.; Agosti, V.; Olivo, E.; Concolino, A.; De Angelis, M.T.; Tammè, L.; Fiumara, C.V.; Cuda, G.; Scumaci, D. Histone proteomics reveals novel post-translational modifications in breast cancer. Aging 2019, 11, 11722-11755. [CrossRef] [PubMed]

67. Hassan, A.S.; Awad, H.M.; Magd-El-Din, A.A.; Hafez, T.S. Synthesis and in vitro antitumor evaluation of novel Schiff bases. Med. Chem. Res. 2018, 27, 915-927. [CrossRef]

68. Hassanin, H.M.; Serya, R.A.; Abd Elmoneam, W.R.; Mostafa, M.A. Synthesis and molecular docking studies of some novel Schiff bases incorporating 6-butylquinolinedione moiety as potential topoisomerase II $\beta$ inhibitors. R. Soc. Open Sci. 2018, 5, 172407. [CrossRef]

69. Saturnino, C.; Caruso, A.; Iacopetta, D.; Rosano, C.; Ceramella, J.; Muia, N.; Mariconda, A.; Bonomo, M.G.; Ponassi, M.; Rosace, G.; et al. Inhibition of human topoisomerase II by $N, N, N$-trimethylethanammonium iodide alkylcarbazole derivatives. ChemMedChem 2018, 13, 2635-2643. [CrossRef]

70. Iacopetta, D.; Rosano, C.; Puoci, F.; Parisi, O.I.; Saturnino, C.; Caruso, A.; Longo, P.; Ceramella, J.; Malzert-Freon, A.; Dallemagne, P.; et al. Multifaceted properties of 1,4-dimethylcarbazoles: Focus on trimethoxybenzamide and trimethoxyphenylurea derivatives as novel human topoisomerase II inhibitors. Eur. J. Pharm. Sci. 2017, 96, 263-272. [CrossRef]

71. Saipriya, D.; Prakash, A.C.; Kini, S.G.; Bhatt, V.G.; Pai, S.R.; Biswas, S.; Mohammed, S.K. Design, synthesis, antioxidant and anticancer activity of novel Schiff's bases of 2-amino benzothiazole. Ind. J. Pharm. Educat. Res. 2018, 52, S333-S342. [CrossRef] 
72. Uddin, N.; Rashid, F.; Ali, S.; Tirmizi, S.A.; Ahmad, I.; Zaib, S.; Zubir, M.; Diaconescu, P.L.; Tahir, M.N.; Iqbal, J.; et al. Synthesis, characterization, and anticancer activity of Schiff bases. J. Biomol. Struct. Dynam. 2020, 38, 3246-3259. [CrossRef] [PubMed]

73. Mahal, A.; Wu, P.; Jiang, Z.H.; Wei, X. Schiff bases of tetrahydrocurcumin as potential anticancer agents. Chem. Sel. 2019, 4, 366-369. [CrossRef]

74. Erturk, A.G. Synthesis, structural identifications of bioactive two novel Schiff bases. J. Mol. Struct. 2020, 1202, 127299. [CrossRef]

75. Suyambulingam, J.K.; Karvembu, R.; Bhuvanesh, N.S.; Enoch, I.V.M.V.; Selvakumar, P.M.; Premnath, D.; Subramanian, C.; Mayakrishnan, P.; Kim, S.H.; Chung, I.M. Synthesis, structure, biological/chemosensor evaluation and molecular docking studies of aminobenzothiazole Schiff bases. J. Ades. Sci. Technol. 2020, 34, 2590-2612. [CrossRef]

76. Kitdumrongthum, S.; Reabroi, S.; Suksen, K.; Tuchinda, P.; Munyoo, B.; Mahalapbutr, P.; Rungrotmongkol, T.; Ounjai, P.; Chairoungdua, A. Inhibition of topoisomerase II $\alpha$ and induction of DNA damage in cholangiocarcinoma cells by altholactone and its halogenated benzoate derivatives. Biomed. Pharmacother. 2020, 127, 110149. [CrossRef]

77. Pozzi, C.; Ferrari, S.; Cortesi, D.; Luciani, R.; Stroud, R.M.; Catalano, A.; Costi, M.P.; Mangani, S. The structure of Enterococcus faecalis thymidylate synthase provides clues about folate bacterial metabolism. Acta Crystallogr. D Biol. Crystallogr. 2012, 68, 1232-1241. [CrossRef] [PubMed]

78. Mishra, V.R.; Ghanavatkar, C.W.; Mali, S.N.; Chaudhari, H.K.; Sekar, N. Schiff base clubbed benzothiazole: Synthesis, potent antimicrobial and MCF-7 anticancer activity, DNA cleavage and computational study. J. Biomol. Struct. Dynam. 2020, 38, 1772-1785. [CrossRef] [PubMed]

79. Bhat, S.S.; Shivalingegowda, N.; Revankar, V.K.; Lokanath, N.K.; Kugaji, M.S.; Kumbar, V.; Bhat, K. Synthesis, structural characterization and biological properties of phosphorescent iridium (III) complexes. J. Inorg. Biochem. 2017, 177, 127-137. [CrossRef]

80. Desai, S.B.; Desai, P.B.; Desai, K.R. Synthesis of some Schiff bases, thiazolidones, and azetidinones derived from 2,6diaminobenzo[1,2-d:4,5-d']bisthiazole and their anticancer activities. Heterocycl. Commun. 2001, 7, 83-90. [CrossRef]

81. Padhye, S.; Yang, H.; Jamadar, A.; Cui, Q.C.; Chavan, D.; Dominiak, K.; McKinney, J.; Banerjee, S.; Dou, Q.P.; Sarkar, F.H. New difluoro knoevenagel condensates of curcumin, their schiff bases and copper complexes as proteasome inhibitors and apoptosis inducers in cancer cells. Pharm. Res. 2009, 26, 1874-1880. [CrossRef] [PubMed]

82. Shokrollahi, S.; Amiri, A.; Fadaei-Tirani, F.; Schenk-Joß, K. Promising anti-cancer potency of 4,5,6,7-tetrahydrobenzo[ $d]$ thiazolebased Schiff-bases. J. Mol. Liq. 2020, 300, 112262. [CrossRef]

83. Morsy, N.M.; Hassan, A.S.; Hafez, T.S.; Mahran, M.R.; Sadawe, I.A.; Gbaj, A.M. Synthesis, antitumor activity, enzyme assay, DNA binding and molecular docking of Bis-Schiff bases of pyrazoles. J. Iran. Chem. Soc. 2021, 18, 47-59. [CrossRef] 